\title{
A case of small-intestinal mucosal atrophy
}

\author{
R. E. BARRY, JOHN S. MORRIS, AND A. E. A. READ \\ From the Department of Medicine, Bristol Royal Infirmary
}

SUMMARY A patient is described with a severe malabsorption syndrome which failed to respond to a gluten-free diet. Although subtotal villous atrophy was present in the jejunal mucosa, histological features of subepithelial fibrosis and apparently normal enterocytes were not suggestive of coeliac disease. The findings of decreased mucosal thickness, of a normal mitotic rate in the crypt cell population, and of the decreased rate of loss of epithelial cells further suggested that the disease process producing the 'flat' mucosa was not that of coeliac disease.

The condition was complicated by ileal ulceration and active tuberculosis.

A satisfactory definition of coeliac disease is not possible in the present state of our knowledge. However, for practical purposes the diagnosis rests on the finding of subtotal villous atrophy at peroral jejunal biopsy in a patient with malabsorption. Some workers believe that a well defined response to gluten withdrawal and/or relapse on its reintroduction is also necessary for absolute identification of the disease (Frazer, 1960; Benson, Kowlessar, and Sleisenger, 1964; Rubin and Dobbins, 1965) because jejunal mucosal changes have occurred in association with several other conditions which include dermatitis herpetiformis (Marks, Shuster, and Watson, 1966), kwashiorkor (Stanfield, Hutt, and Tunnicliffe, 1965), chronic renal failure (Loehry and Creamer, 1966), agammaglobulinaemia (Collins and Isselbacher, 1964), ulcerative colitis (Salem and Truelove, 1965), and Whipple's disease (Chears, Hargrove, Verner, Smith, and Ruffin, 1961).

The purpose of this communication is to describe a patient with malabsorption and a 'flat' jejunal mucosa with features not typical of coeliac disease.

Received for publication 20 January 1970.

\section{Case Report}

A 53-year-old married barmaid presented at another hospital with a four-year history of weight loss amounting to $56 \mathrm{lb}(25.4 \mathrm{~kg})$ and a history of frequent, loose bowel actions for two and a half years. The faeces were fluid or semisolid, bulky, a pale yellow colour, floated on water, and were difficult to flush. Anorexia had been present for six months. Investigation at that time confirmed steatorrhoea (daily fat excretion $7 \cdot 7 \mathrm{~g}$ ) but no jejunal biopsy was obtained. A clinical diagnosis of coeliac disease was made and gluten withdrawn from the diet.

Despite rigid adherence to the diet, bowel symptoms persisted so that the patient lost a further $14 \mathrm{lb}(6.4 \mathrm{~kg})$ in four months. An attack of carpopedal spasm responded to intravenous calcium and from then on she was treated with oral calcium ( $1 \mathrm{~g}$ four times per day)

The patient was referred to the Bristol Royal Infirmary in June 1969 with a history of painful bilateral cervical lymphadenopathy for four weeks. Previously her health had been good but she had attended a chest clinic at the age of 15 years where she was suspected of having pulmonary 
tuberculosis, though she had undergone no specific therapy.

Examination revealed an emaciated, middleaged woman. She appeared anaemic with a smooth, atrophic tongue, angular stomatitis, and pale mucous membranes. There was marked ankle oedema. Enlarged, tender, matted lymph nodes were palpable in the anterior triangle on both sides of the neck. The overlying skin was slightly red but not warm. No other regional lymph nodes were enlarged. Abdominal distension was marked but no free fluid was detectable. There was no abdominal tenderness and no masses were felt. Rectal examination was normal.

\section{Investigations}

Haemoglobin was $10.5 \mathrm{~g} / 100 \mathrm{ml}$ and ESR was 35 $\mathrm{mm}$ /hour (Westergen). Examination of the blood film showed iron deficiency. Serum iron was $86 \mathrm{~g}$ per $100 \mathrm{ml}$ (normal 70 to $180 \mathrm{~g} / 100 \mathrm{ml}$ ), total ironbinding capacity $390 \mathrm{~g}$ per $100 \mathrm{ml}$. Urinary d-xylose excretion was $1.5 \%$ of a $5 \mathrm{~g}$ oral dose in five hours, and an oral glucose tolerance curve

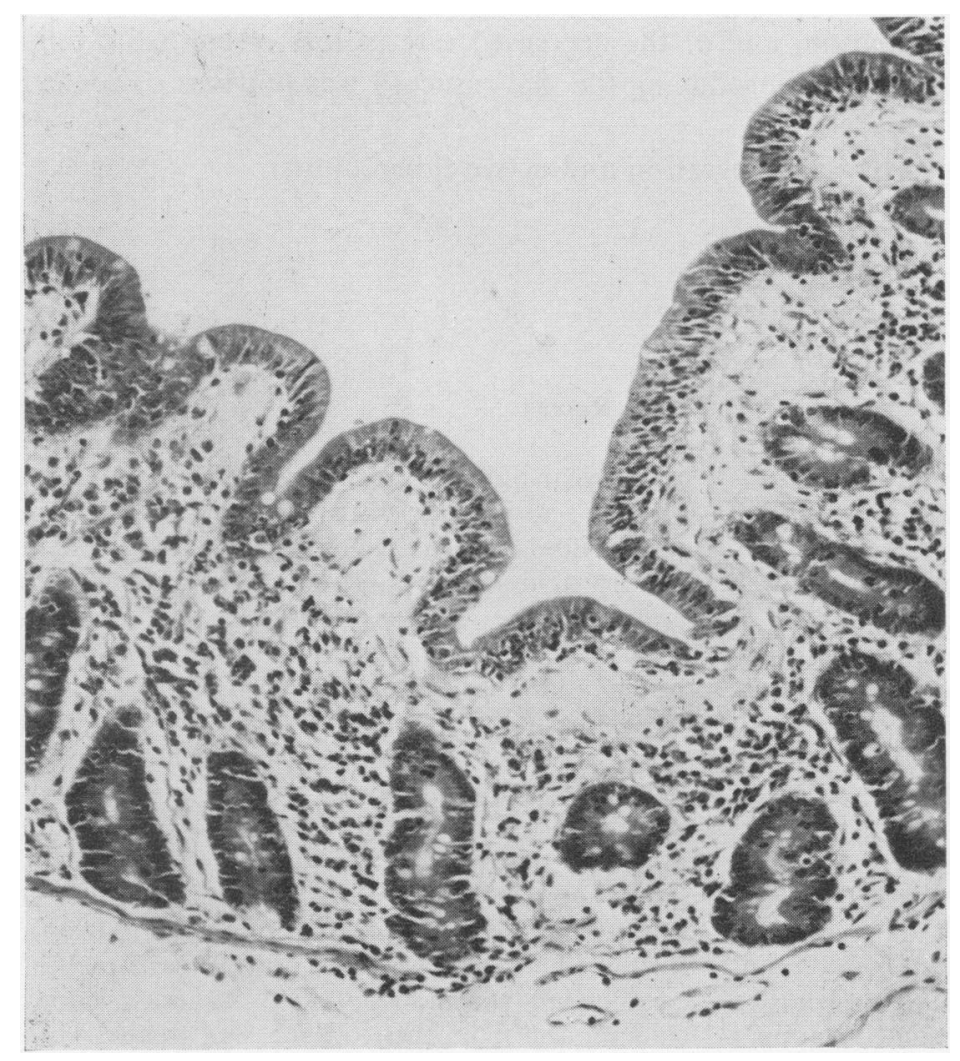

Fig. 1 Histological section of the duodenum, formalin fixation immediately after death. The collagenous band appears as an eosinophillic hyaline zone immediately beneath the enterocyte layer. The enterocytes appear normal, mature, columnar cells. (Haematoxylin and eosin.) was flat (less than $10 \mathrm{mg}$ rise above the fasting level). Serum albumin was $2 \cdot 1 \mathrm{~g} / 100 \mathrm{ml}$ and total serum globulin $3.5 \mathrm{~g} / 100 \mathrm{ml}$ with raised $\gamma$ and $\alpha_{2}$ fractions. The alkaline phosphatase was $27 \mathrm{KA}$ units per $100 \mathrm{ml}$ (normal 3-13 units $/ 100 \mathrm{ml}$ ). Faecal fat excretion was $34 \mathrm{~g}$ per day on a $75 \mathrm{~g}$ fat diet. A Schilling test showed a $0.4 \%$ excretion of the labelled oral dose of vitamin $B_{12}$ (normal $>12 \%$ ). Radiological examination of the small bowel using Raybar showed marked flocculation and dilatation of jejunal loops but there was no radiological evidence of malignancy. The presence of two calcified mesenteric lymph nodes was noted. Culture of the jejunal aspirate both aerobically and anaerobically produced an insignificant growth of mouth organisms.

A peroral duodenal biopsy showed subtotal villous atrophy and round cell infiltration of the lamina propria. An additional feature was the presence of a well defined sheet of eosinophilic hyaline material which was shown to be collagen by staining with van Gieson's and Masson's trichrome stains. This was situated immediately beneath the intestinal epithelial cell layer in the lamina propria (Fig. 1). Paneth cells were present in normal numbers.

The rate of loss of small bowel epithelial cells, measured using the technique described by Croft, Loehry, Taylor, and Cole (1968b), was $36 \pm 4 \mathrm{~m} \mu \mathrm{g}$ atoms DNA $-\mathrm{P} / 5 \mathrm{~cm}$ bowel $/ \mathrm{min}$ (normal range 45-54 $\mathrm{m} \mu \mathrm{g}$ atoms DNA-P/5 cm/min, mean $50 \pm 4)$.

Histological examination of a cervical node biopsy revealed caseating tuberculosis.

\section{Progress}

The tuberculous nodes and a communicating abscess cavity were surgically drained and the patient was treated with streptomycin $(0.75 \mathrm{~g}$ per day) and isoniazid ( $200 \mathrm{mg}$ daily) intramuscularly.

Three weeks later, she developed erysipelas of the right foot which responded to penicillin, and later a deep venous thrombosis in the left calf. A few days later, the patient complained of severe, generalized abdominal pain of rapid onset. On examination she was shocked with a tender, distended, rigid, and silent abdomen. The clinical diagnosis was that of a perforated abdominal viscus but despite resuscitative measures the patient died before surgery could be undertaken.

\section{Necropsy}

A necropsy was performed three hours after death. The presence of tuberculous lymphadenitis of the neck was confirmed. The peritoneal cavity contained 4.5 litres of straw-coloured fluid containing a few strands of soft fibrin. Careful examination of the whole length of the bowel

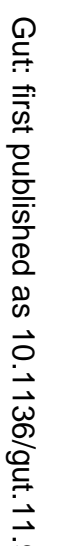




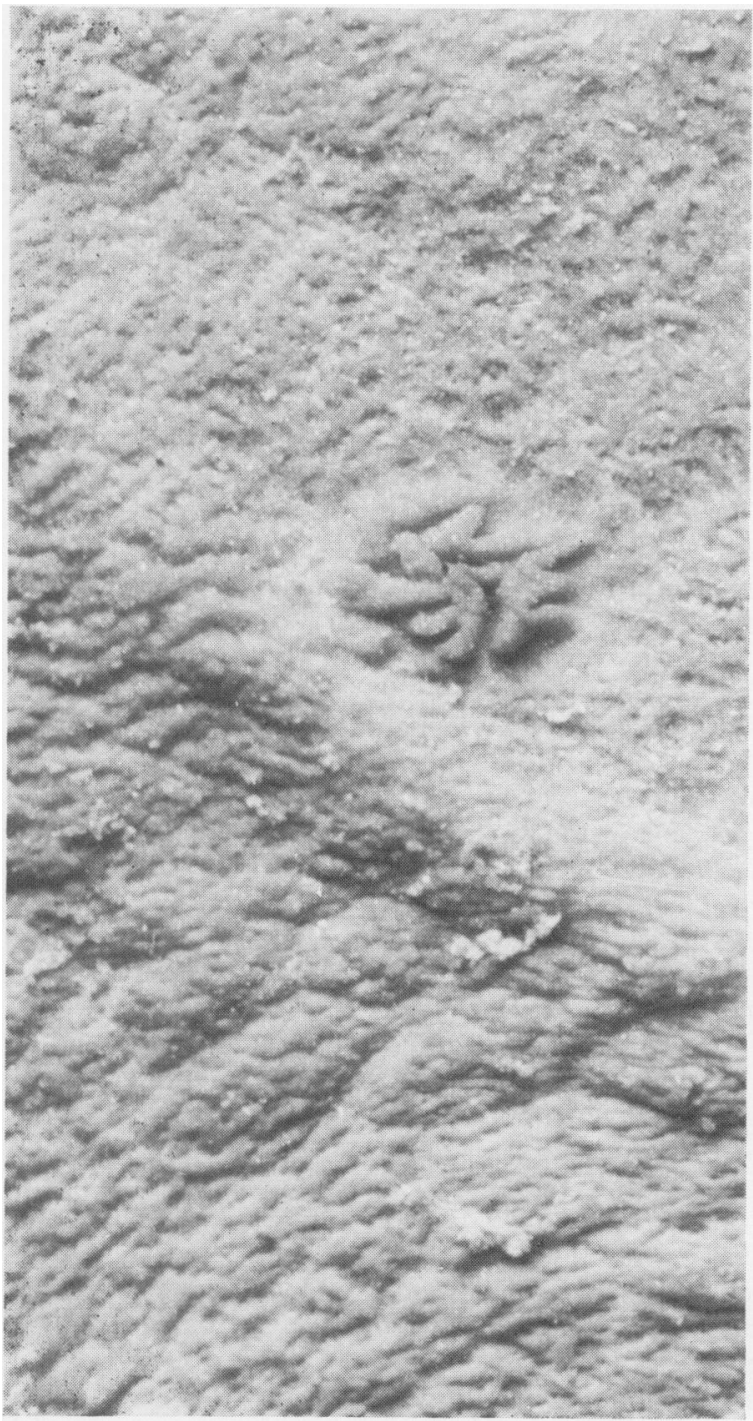

Fig. 2

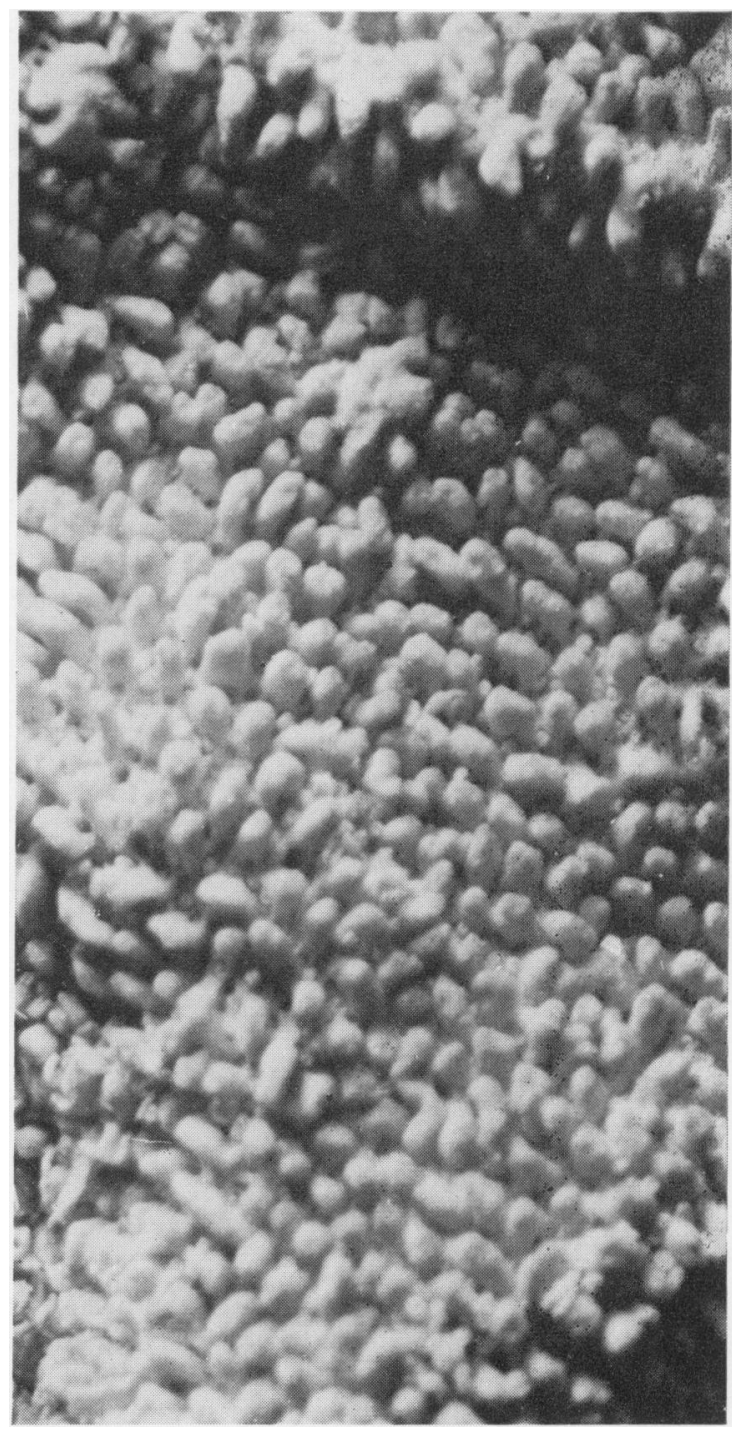

Fig. 3

Fig. 4

Fig 2. Dissecting microscope appearance of formalin-fixed jejunal mucosa $30 \mathrm{~cm}$ from the ligament of Treitz, showing a 'flat' mucosa with the occasional island (2-3 mm diameter) of convolutions (eosin).

Fig. 3. Dissecting microscope appearance of autolysed, formalin-fixed ileal mucosa $30 \mathrm{~cm}$ from the ileocaecal valve showing relatively normal villous architecture.

Fig. 4. Histological section of jejunum $50 \mathrm{~cm}$ from the ligament of Treitz. The well defined collagenous band is well shown (van Gieson). 
failed to reveal any macroscopic or microscopic evidence of perforation or malignancy and no cause for the peritonitis was found. The spleen weighed only $12 \mathrm{~g}$ (normal $150-200 \mathrm{~g}$ ); further evidence of lymphoid atrophy was found in the Peyer's patches and mesenteric lymph nodes. Calcified mesenteric lymph nodes were found but there was no evidence of active abdominal tuberculosis.

Examination of the small bowel revealed subtotal villous atrophy from the pyloric canal to within $3 \mathrm{ft}$ of the ileocaecal valve (Fig. 2). The distal ileum contained small but normal shaped villi (Fig. 3). A thin, well defined band of collagen was present beneath the epithelial cell layer in the duodenum and jejunum in all sections examined (Fig. 4). In the ileum, however, the collagen was not present as a discrete band but was localized to the tips of the villi as loose strands.

Multiple, discrete ulcers were present in the terminal ileum, caecum, and proximal half of the ascending colon. Histological sections of the ileal ulcers showed nonspecific ulceration with minimal cellular reaction and no thickening of the bowel wall. Mycelia were noted in the ulcerated areas. The total mucosal thickness was $135 \mu \pm 4$ (normal range $520 \mu \pm 68$ ) and the mitotic index of the crypt cell population was $2.2 \%$ (normal) (Padykula, Strauss, Ladman, and Gardner, 1961).

\section{Discussion}

Although some authorities believe a favourable response to gluten withdrawal to be an essential diagnostic criterion of coeliac disease, it is clear that failure to respond clinically may result from intercurrent illness such as malignancy or infection. In the present case, failure to respond was associated with a histological abnormality similar to, but not typical of, coeliac disease. The relevance of the tuberculosis coexisting with this histological appearance or with the lack of response to restriction of dietary gluten is not clear, although a flat jejunal mucosa has been described in association with active tuberculosis (Hindle and Creamer, 1965). Failure to respond to withdrawal of dietary gluten has also been described in a group of patients in whom Paneth cells were absent from the jejunal mucosa (Creamer and Pink, 1967). In our patient Paneth cells were present in normal numbers.

The finding of a well defined band of collagen immediately beneath the enterocyte layer is unique in our experience but has been noted elsewhere (Schein, 1947; Himes and Adlersburg, 1957; Weinstein, Shimoda, Brow, and Rubin, 1969). It was present in all sections examined, being most compact in the jejunum, well defined in the duodenum, and localized to the villous tips in the ileum. Where crypts were sectioned longitu- dinally it could be seen that the collagenous band was in direct continuity with the pericryptal fibroblast sheath described by Kaye, Pascal, and Lane (1968).

The surface epithelial cells of the 'flat' mucosa appeared microscopically to be healthy columnar cells compared with the usual degenerate cuboidal cells present in typical coeliac disease (Fig. 1).

In coeliac disease, the rate of loss of surface epithelial cells in the small bowel is increased (Croft, Loehry, and Creamer, 1968a) and the increased mitotic rate in this disease is well recognized. However, direct measurement of this loss rate in this patient showed it to be subnormal.

Nonspecific ulceration of the small bowel has been described in coeliac disease (Bayless, Kapelowitz, Shelley, Ballinger, and Hendrix, 1967). The cause is unknown. It has been suggested that the high rate of cell loss which occurs in coeliac disease may result in a failure of epithelial cell regeneration leading to ulceration (Davidson, 1969). This is an unlikely explanation in the present case as the rate of cell loss was below the range we have found in normal people and in patients with proven typical coeliac disease. Further, the ulceration occurred only in areas of relatively normal mucosa. Similarly, in examples cited by other authors (Bayless et al, 1967; Davidson, 1969) the ulceration can be seen in areas where the villous architecture is undisturbed. It has been shown that normal mucosal architecture infers a normal rate of cell loss (Loehry and Creamer, 1969).

It has been repeatedly pointed out that the term 'atrophy' as a description of the mucosal appearances of the small bowel in coeliac disease is misleading since the total mucosal thickness is usually within the normal range and the mitotic rate increased (Rubin and Dobbins, 1965; Schenk, Samloff, and Klipstein, 1965). This case was again unusual in that a decreased mucosal thickness and a normal mitotic index for the crypt cells was found.

It is believed that this patient had a generalized wasting disease of obscure aetiology, antedating and out of proportion to the tuberculous adenitis, which produced a true atrophy of the small intestinal mucosa and a severe malabsorption syndrome. Whether this represents a histological variety of coeliac disease or a disease entity hitherto undescribed remains to be seen; certainly the collagenous tissue may be a distinguishing feature. Clearly, further descriptions of similar cases are required.

We are indebted to Dr D. H. Isaac for originally referring the case, to Mrs $\mathrm{H}$. V. Ray for skilled technical assistance, and to Dr J. Cornes who performed the necropsy. 
References

Bayless, T. M., Kapelowitz, R. F., Shelley, W. M., Ballinger, W. F., and Hendrix, T. R. (1967). Intestinal ulcerationa complication of celiac disease. New Engl. J. Med., 276, 996-1002.

Benson, G. D., Kowlessar, O. D., and Sleisenger, M. H. (1964). Adult coeliac disease with emphasis upon response to the gluten-free diet. Medicine (Baltimore), 43, 1-40.

Chears, W. C., Hargrove, M. D., Verner, J. V., Smith, A. G., and Ruffin, J. M. (1961). Whipple's disease. A review of 12 patients from one service. Amer. J. Med., 30, 226-234.

Collins, J. R., and Isselbacher, K. J. (1964). Treatment of adult celiac disease (non tropical sprue). New Engl.J. Med., 271, 1153-1156.

Creamer, B., and Pink, I. J. (1967). Paneth cell deficiency. Lancet, 1, 304-306.

Croft, D. N., Loehry, C. A., and Creamer, B. (1968a). Small bowel cell-loss and weight-loss in the coeliac syndrome. Lancet, 2, 68-70.

Croft, D. N., Loehry, C. A., Taylor, J. F. N., and Cole, J. (1968b). DNA and cell loss from normal small intestinal mucosa. Lancet, 2, 70-73.

Davidson, A. R. (1969). Recurrent benign ileal ulcer occurring with the coeliac syndrome. Brit. med.J., 3, 341

Frazer, A. C. (1960). Pathogenetic concepts of the malabsorption syndrome. Gastroenterology, 38, 389-398.

Himes, H. W., and Adlersburg, D. (1957). Pathologic studies in idiopathic sprue J. Mt Sinai Hosp., 24, 251-272.

Hindle, W., and Creamer, B. (1965). Significance of a flat smallintestinal mucosa. Brit. med. J., 2, 455-458.
Kaye, G. I., Pascal, R. R., and Lane, N. (1968). Colonic pericryptal fibroblast sheath: roplication, migration and cytodifferentiation of a mesenchymal cell system in adult tissue. Gastroenterology, 54, 835-865.

Loehry, C. A., and Creamer, B. (1966). Postmortem study of small intestinal mucosa. Brit. med. J., 1, 827-829.

Loehry, C. A., and Creamer, B. (1969). Three-dimensional structure of the human small intestinal mucosa in health and disease. Gut, 10, 6-12.

Marks, J., Shuster, S., and Watson, A. J. (1966). Small-bowel changes in dermatitis herpetiformis. Lancet, 2, 1280-1282.

Padykula, H. A., Strauss, E. W., Ladman, A. J., and Gardner, F. H. (1961). A morphologic and histochemical analysis of the human jejunal epithelium in non tropical sprue. Gastro?nterology, 40, 735-765.

Rubin, C. E., and Dobbins, W. O. (1965). Peroral biopsy of the small intestine. Gastroenterology, 49, 676-697.

Salem, S. N., and Truelove, S. C. (1965). Small intestinal and gastric abnormalities in ulcerative colitis. Brit. med.J., 1, 827-831.

Schein, J. (1947). Syndrome of non tropical sprue with hitherto undescribed lesions in the small intestine. Gastroenterology, 8, 438-460.

Schenk, E. A. Samloff, I. M. and Klipstein, F. A. (1965). Morphologic characteristics of jejunal biopsy in celiac disease and tropical sprue. Amer. J. Path., 47, 765-781.

Stanfield, J. P., Hutt, M. S. R., and Tunnicliffe, R. (1965). Intestinal biopsy in kwashiorkor. Lancet, 2, 519-523.

Weinstein, W. M., Shimoda, S. S., Brow, J. R., and Rubin, C. E. (1969). International Conference on Coeliac Disease. Royal Postgraduate Medical School, London. 